ARTICLE HISTORY: Received: September 13, 2021 Accepted: November 5, 2021 Published: November 13, 2021

\title{
СПЕЦИФИКА СОВРЕМЕННОГО ХОРЕОГРАФИЧЕСКОГО ИСКУССТВА КАК ФЕНОМЕНА КУЛЬТУРЫ РОССИИ
}

\author{
Кочеров Е.В. \\ аспирант 2 курса теории и истории культуры (культурология) \\ Московского Государственного Института Культуры. \\ Россия
}

\begin{abstract}
Аннотация. Современное хореографическое искусство в России рассматривается автором как культурный феномен, влияющий на перспективу развития общества в разных аспектах. Замечено отражение характера и менталитета русского народа, который транслируется с помощью инструмента телесной коммуникации. Автором отмечается, что в самом современном хореографическом искусстве принцип народности ярко выражен как в стилях, так и в автономном фольклоре, в его репрезентации, отделяющую от аналогичных зарубежных видов искусства. Аргументируется позиция о том, что в древности танцевальная обрядовость играла важную роль в миропонимании и взаимодействии человека с реальностью, которая несла гармонизацию во многих сферах жизнедеятельности. Предки современных россиян - древние славяне умели использовать глубинные знания о мироздании с помощью разного инструментария, одним из них была танцевальная обрядовость. Автор делает акцент на то, что современное общество уходит от традиционного уклада жизни, накопленного далекими предками, ставя на передний план технический прогресс. Обращается особое внимание на традиционную форму взаимодействия человека и искусства с элементом тактильности, привычного для успешной реализации преподавательской сферы на базе современного хореографического творчества. Рассматривается частичный переход социогуманитарного знания в онлайн-режим, что может послужить ряду проблем и ухода человека от истинного, духовного преопределенного пути. Также выделяется проблема свободы и порядка в танце; параллельно обращается внимание на важность гармоничного соединения традиционного наследия в танце с многоаспектной новизной, которую требуют современные реалии.

Ключевые слова: современное хореографическое искусство, народность в современной хореографии России, роль танцевальной обрядовости в древности, традиционная форма взаимодействия человека с искусством, современное хореографическое искусство в онлайн-режиме, современное хореографическое искусство как феномен культуры, хореография, пляска и танец.
\end{abstract}

На сегодняшний день сохранилось множество видоизмененных форм культуры, которые постоянно трансформируются, соответствуя временным запросам общества. Ярким прообразом такой культуры является современное хореографическое искусство, породившее новую парадигму субъективного восприятия и способ эмоциональной выразительности.

Современное хореографическое искусство - это поиск нестандартного способа самовыражения танцевальной деятельности, внедрение новых технических аспектов, уход от устоявшихся стилевых концепций и композиционных приемов освоения сценического пространства, новая возможность телесной экспликации. Понимание танца как онтологической системы в современных условиях уходит от вертикального типа развития с иерархической сменой уровней и устоявшимся танцевальным языком внутри отдельно взятой хореографической системы в сторону их динамики и расширения подвидов.

Успешное продвижение в сфере современного хореографического искусства не может быть реализованным без учета соответствующих традиций танцевальной обрядовости, в контексте гармоничного взаимодействия человеческого тела с законами природы, и опыта целых цивилизаций, накопившегося за все время существования танца как цивилизационного культурного явления. Важным фактором совершенствования современного хореографического искусства в России является сохранение культурного наследия народов. Именно народность несет основополагающий пласт в перспективе развития хореографии России. Она выделяется на международной арене и солидно презентует себя в конкурентных условиях с зарубежными представителями данного искусства. Современное хореографическое искусство содержит в себе синтез многообразных форм и подвидов танцевальной культуры со смешанной национальностью, но, если речь идет о современном хореографическом искусстве России, то концепт репрезентации данного искусства должен соответствовать характеру и менталитету русского человека (при удачной трансляции этих факторов посредством пластически-хореографической коммуникации).

Ученые, рассматривающие танец в контексте культурологического, искусствоведческого, педагогического подходов, выделяют народно-сценический танец, который наиболее чаще исследуется, так как предрасположен к анализу многих значимых аспектов одновременно, таких как: методические разработки, народность в танцевальном искусстве, разновидность народной хореографии, обрядовость и традиционность танцевальной 
культуры, а если рассматривать тенденцию развития хореографии, отталкиваясь от древней цивилизации и ее танцевально-обрядовой жанровой специфики, то именно народно-сценический танец берет те истоки от древнего ритуального танца предков, которые несут в себе глубокую смысловую нагрузку. Научным доказательством данного суждения является специфика термина «народность», ведь именно она отражает эпос и характерные черты того сословия или групп многонационального населения, к которому относится.

Затрагивая вопрос о предках современных россиян, следует проанализировать феномен древних славян со своей огромной системой миропонимания и ведической культурой. В данном культе замечен интерес к изучению хореографического искусства как важной культурной ценности. Подтверждение данной мысли можно найти в «Книге Света» Славяно-Арийских Ведов, также, ярким источником для доказательства этой позиции являются работа «Веды Руси Веды Булгар Пра-Веды. Анализируя дефиницию славянской исторической терминологии в вышеупомянутых источниках, отметим, что для западных славян, как и для восточных «хоро» является более старым понятием, чем понятие танец, которое пришло к ним в период римского владычества. Впитав в себя языковые танцевальные традиции чехов, словаков, сербов и латинян, он хранил наиболее богатый танцевальный язык. Славяно-угорский корень - кӧr в значении хоровод, к которому уже добавлен латинский корень tánc, точнее переводится как круговой танец, где круг является не формой, а рисунком.

В древности танцевальная обрядовость и ее значение в понимании о мироздании играла достаточно значимую роль. Благодаря танцевальному искусству у общества всегда будет наблюдаться одно из самых важных качеств в человеке - гармония. Сбалансированное взаимодействие телесного и духовного аспектов помогают человеку сохранять благоразумие, на которое в современной повседневности с огромной скоростью усиливается давление. Современный человек ушел от своих традиций, накопленных предыдущими поколениями. На территории нынешней России одной из таких традиций были обрядовые танцы, в которых участвовали все представители общины (важным аспектом было поддержание культуры). Эти обычаи совершались с разными целями: благодарность законам Вселенной за плодородную почву, почитание Богов в различные времена года, празднования культовых мероприятий. Очевидно, не вся информация, накопленная веками, сохранилась до настоящего времени как культурный артефакт, часть ее зашифровалась в лексическом материале исполнителей обрядового танца, предков современных россиян, - древних славян. К сожалению, на сегодняшний день, не существует возможности наглядного ознакомления с первоначальной атмосферой древнего ритуального танца, так как технолого-цифровой аспект был, по одной из научных версий, недоразвит, а по другой, - был перенасыщен технологиями, в сравнении с нынешней ситуации по данной проблеме, и после чего было совершенно полное обновление и как бы возврат к предыдущему опыту развития человечества. Единственная точная передача информации от предков могла сохраниться в генотипе и проявляться в каждом поколении, с учетом визуально-тактильного продолжения традиционного обучения танцевальному искусству. Причиной ухода от традиционной формы культурного наследия, по мнению автора, служат прогресс технического уровня и переход на повседневную цифровизационную жизнедеятельность, которая заменяет элемент тактильности, актуального для практического освоения современного хореографического искусства и его дальнейшей продуктивно-целостной трансформации. Человек уходит от своего привычного активного образа жизни и все больше заменяет его автоматизацией и компьютеризацией. Именно поэтому важно сохранять культурно-устойчивую форму выражения творческой действительности, в которой общество может «переключиться» от высокого темпа новой реальности. Современное хореографическое искусство, в данном случае, является важнейшим механизмом для культуры России в процессе поиска сбалансированного состояния человека, его мировосприятия и одухотворённости.

Известно, что представители элитного современного американского сообщества осознали степень негативного влияния всемирной сети и обострение технолого-цифрового прогресса, связи с этим, более молодым представителям государства, с раннего детства транслируют традиционную форму художественноэстетической инкультурации (посещение выставок, театров, музыкальных концертов, мюзиклов и т д). Это является показателем того, что именно живая взаимосвязь с искусством несет в себе как с архаических времен гармоничный и традиционный формат взаимодействия, так и с современной антиутопической позиции, максимально традиционную форму коммуникации человека с творчеством, и отражает отсутствие негативного воздействия на человека, под видом прогрессирующей компьютеризации, нехотя побуждая его к активности (но внедрение креативных технологий в творческий процесс - это естественный и неизбежный фактор, который также возможен и актуален, но в данном виде искусства несет вторичный характер и выступает в аспекте «продвижения»). По данной проблеме, у американского сообщества, в контексте традиционного понимания взаимодействия человека с искусством, представляется, выбрана наиболее оптимальная модель на пути реализации перспективного будущего без «лишнего» технического излучения и зависимости от электротехники. Процесс полного перехода в эволюционном развитии современного общества, с высокими инновационными технологиями и безвозвратного традиционного способа взаимодействия с культурой, утопичен для современного хореографического искусства. Общество, безусловно, развивается, облегчая, тем самым, привычное нам существование, но уход от родоначальной формы искусства в целом, в том числе и современной хореографии, может привести к разрушению культурно-исторического уклада, либо к переходу на совершенно 
новое, неизвестное еще обществу взаимодействие с искусством. Наблюдать предпосылки такого «перехода» всему миру пришлось в 2020г. на карантине, где высокое техническое освещение в буквальном смысле спасло социогуманитарный культурный резерв, когда представителям гуманитарной науки и искусства пришлось переключиться на практику в онлайн-коммуникациях. Очевидно, что современное хореографическое искусство в России и за рубежом может иметь вектор перспективного развития в онлайн-режиме лишь в частных случаях, и поэтому данной сфере будет стабильнее всего развивать традиционную форму освещения художественнохореографической инкультурации, и главным аргументом для этого является, в первую очередь, здоровая активность человека и психофизиологическое развитие без ограничительных мер. Данная проблематика внедрения технологий в искусство остро стоит не только в России, но и во всем мире.

Потребность и актуальность в изучении современного хореографического искусства возросла, как с профессионально-исполнительской точки зрения, так и с позиции зрителя-наблюдателя. Этому свидетельствует смена научного вектора познания с классического и народного направлений хореографического искусства на современное. Подвиды и жанровая специфика современного хореографического искусства значительно расширились и влияние танцевального творчества на массовую культуру напрямую происходит через все современные каналы коммуникации с потенциальным потребителем. Хореографическое искусство стремительно развивается, как и любая другая сфера жизнедеятельности человека на современном этапе. Чтобы в полной мере рассмотреть историю изучения хореографического искусства, необходимо обратиться к ее истокам и к самому определению танца.

Танец, в традиционном трактовании, - это вид искусства, в котором средством создания художественного образа являются движения и положения человеческого тела [1, с. 623]. Нельзя не согласиться с данным суждением автора, ведь танец подразумевает активность и движенческий мотив, в то же время, как на примере статического выражения он может отображать неподвижность под видом «поз». С помощью танцевального искусства человек учится взаимодействовать с миром на более тонком уровне восприятия материи через управление энергиями, а любое управление - это направление вектора рефлексивного внимания. Одной из главных особенностей всех видов искусств, связанных с самовыражением, является чувственное восприятие своей натуры и трансляция ее во внешнюю среду. Конечно, возможен путь реализации художественной идеи через вдохновение от внешних факторов, но ресурс, лежащий в основе, как стержень, находится в самом чувственном восприятии человека и именно в этом заключается фундамент не только творческой деятельности, а абсолютно любой, где необходим воспроизводящий элемент. В танцевальном же искусстве в особенности актуально чувственное восприятие и самовыражение внутреннего ощущения через движение, поэтому изучение танца не останавливается только на моторно-ритмическом выражении избыточной энергии и повторении из поколения в поколение, на первый взгляд, бессмысленных традиционных и обрядовых танцевальных композиций.

А.В. Тугай, в своей статье «Методологические подходы к изучению танца», пишет: «Установлено, что предрасположенность к танцу развивается разными путями у различных групп людей, а его смысл и значение связаны с иным феноменом цивилизации, следовательно, его изучение приобретает огромное значение для истории всего человечества. Прошло много веков, мир неузнаваемо изменился, и в настоящее время танец представляет собой активно развивающееся явление, вызывая тем самым особый интерес со стороны ученых и исследователей...» [5, с. 218] Автор упоминает определение «феномен цивилизации», что является актуальным для данной темы исследования, так как термин «цивилизация» отождествляется с термином «культура». Человек создает целую цивилизацию; с помощью перехода на более совершенный уровень активируются инновационные возможности, наблюдается рост, точно так же человек создает и культуру. В русский язык слово танец вошло в XVII в. До того периода в употреблении было общеславянское понятие - пляска, и уже в начале XVIII в. танец впервые обнаруживается в словарях русского языка. А.В. Тугай, в своей статье «Методологические подходы к изучению танца», пишет: «С конца XIX в. танец и пляска употребляются как синонимы. Проникнув в русский язык, слово танец стало более популярным и все чаще употребляемым по сравнению со словом пляска.» [5, с. 114] Но в этих, на первый взгляд, синонимичных понятиях есть весовые отличия, и современные исследователи истории танца указывают на них. В своей работе «Танец: опыт понимания...» Сироткина И.Е. пишет: «Слово «танец» заимствовано из немецкого языка (der Tanz), a «пляска» коренное русское. [4, с. 86] Также данный исследователь указывает на то, что, если танец и пляску расположить по шкале, то пляска окажется ближе к полюсу свободы, а танец - ближе к полюсу порядка. Говоря о термине, «пляска», можно утверждать, что он и отражает свою смысловую идеологию в контексте своей принадлежности к России и олицетворяет силу свободного духа ее жителей. По И. Е. Сиротиной, танец и пляска - слова концепты с разным происхождением, смыслом и вытекающей актуальной проблематикой - проблемы свободы и порядка в танце.

Танец как культурный феномен, влияющий на эволюцию человеческой жизни, (его роль в социуме, начиная от первобытного общества) рассматривает исследователь В. В. Ромм в своем труде «Танец как фактор эволюции человеческой культуры». В данной работе рассматривается изучение культуры человека путем анализа дансологии (совокупности изученного материала о танцевальном искусстве), что является важным 
разделом культурологии. В. В. Ромм изучает семантику пластического движения древнего человека, исходя из результатов анализа объектов, которым возраст более 10 тысяч лет. Он указывает на то, что танец в древности являлся специфичным способом передачи информации. Также автор обосновывает определение нового направления в хореографии -палеохореографию, которая изучает первобытную танцевальную культуру на основе артефактов. [3, с. 5]

Л.Т. Дьяконова, в своей статье «Танец как феномен культуры» обращает внимание на эволюционный характер танца: «Феномен танца в процессе эволюции культуры человеческого общества на каждом культурноисторическом этапе выступал как механизм выражения духовно-эстетического наполнения соответствующей эпохи» [2, с. 158]. Следовательно, современное хореографическое искусство - это отражение коллективной души, в котором отображаются переживания человека и его притяжение к инновационному. В нем, в какой-то степени, прослеживаются как поиски человека в разных сферах, так и наоборот истинное понимание о мироздании.

Таким образом, изучение феномена современного хореографического искусства подтверждает свою актуальность: активизируется творческая составляющая человека, характерная современной танцевальной сфере, которая способствует нравственно-эстетическому и духовному развитию, повышению инкультурационного уровня человека, препятствует полному переходу в онлайн индустрию; наблюдается социализация народного искусства посредством хореографии в рамках учебных заведений, любительских и профессиональных коллективах; приобретаются и развиваются новые идеалы, обогащающие социокультурное пространство. Современное хореографическое искусство, по мнению автора, должно отражать культуру на данном этапе эволюции, с четким художественным образом соответствующей эпохи и настроению общества в ней, при этом, транслируя уже накопленный традиционный опыт народа и его наследие. Важно, в условиях быстрого темпа развития и информационного давления, не терять традиционную индивидуальность искусства, но в то же время модернизировать его креативными технологиями и искать способы балансировки этих компонентов, ведь самое сакральное находится в разрезе двух взаимозависимых факторов искусства: новизны и традиции. Новизна при гармоничном взаимодействии с традиционной формой искусства порождает феномен культуры, а проблема свободы и порядка в танце является актуальной и требует углубленного исследования хореографического искусства современными учеными.

\section{Список литературы:}

1. Григорович Ю. Балет: энциклопедия / под ред. - Москва: Советская энциклопедия, 1981. - 623 с.

2. Дьяконова, Л.т Общество. Среда. Развитие (Terra Humana) 3 (20), 2011// Танец как феномен культуры. $258 \mathrm{c}$.

3. Ромм, В. В. Танец как фактор эволюции: автореф. дис. ... д-ра культурологии: 24.00 .01 [Электронный pecypc] / В. В. Ромм. - Барнаул, 2006. http://www.dissercat.com/content/tanets-kak-faktor-evolyutsiichelovecheskoikultury.

4. Сироткина И. Е. Танец: опыт понимания/Эссе/Знаменитые хореографические постановки и перформансы/ Антология текстов о танце- М.; СПб.: Бослен; Издательство Европейского университета в СанктПетербурге, 2020.-256c.

5. Тугай А.В. Вестник Челябинского государственной академии культуры и искусств. 2014 / 2(38) // Методологические подходы к танцу, 2014. - 218с

6. Шпенглер, О. (1993) Закат Европы. Очерки морфологии мировой истории. 1. Гештальт и действительность / пер. с нем., вступ. ст. и примеч. К. А. Свасьяна. М.: Мысль. 663 с. 